\title{
Metabolic and endocrine profiles and hepatic gene expression of Holstein cows fed total mixed ration or pasture with different grazing strategies during early lactation
}

Ana Laura Astessiano ${ }^{1 *}$, Ana Meikle², Maite Fajardo ${ }^{1}$, Jorge Gil ${ }^{3}$, Diego Antonio Mattiauda ${ }^{1}$, Pablo Chilibroste ${ }^{1}$ and Mariana Carriquiry ${ }^{1}$

\begin{abstract}
Background: In dairy mixed production systems, maximizing pasture intake and total mixed ration (TMR) supplementation are management tools used to increase dry matter and energy intake in early lactation. The objective was to evaluate metabolic and endocrine profiles and hepatic gene expression of Holstein cows fed either TMR ad libitum (without grazing) or diets combining TMR (50\% ad libitum DM intake) and pasture with different grazing strategies ( $6 \mathrm{~h}$ in one grazing session or $9 \mathrm{~h}$ in two grazing sessions) in early lactation. Pluriparous cows were grouped by calving date, blocked within group by body weight and body condition score (BCS) and randomly assigned to one of three feeding strategies from calving (day 0) to 60 days postpartum: control cows fed TMR ad libitum (G0; confined cows fed $100 \%$ TMR without access to pasture), pasture grazing with 6 h of access in one session supplemented with $50 \%$ TMR (G1), and $9 \mathrm{~h}$ of access in two sessions supplemented with $50 \% \mathrm{TMR}(\mathrm{G} 2)$.

Results: Net energy (NE), but not metabolizable protein (MP), demands for maintenance and/or milk increased in G2 when compared with G1 and G0 cows, respectively. However, NE and MP balances were lower in G1 and G2 than G0 cows. Cow BCS at +55 days was greater in $\mathrm{G} 0$ than $\mathrm{G} 2$ cows and probability of cows cycling during the first month was greater in $\mathrm{G} 0$ and $\mathrm{G} 1$ than $\mathrm{G} 2$ cows. During the postpartum period, non-esterified fatty acids were greater in $\mathrm{G} 1$ than $\mathrm{G} 2$ and $\mathrm{G} 0$ and $\beta$-hydroxybutyrate was greater in $\mathrm{G} 1$ and $\mathrm{G} 2$ than $\mathrm{G} 0$ cows. Plasma insulin was greater and insulin-like growth factor (IGF)-I tended to be greater in G0 than G2 cows, leptin was greater in G2 and G0 and adiponectin were greater in G2 cows. Hepatic expression of growth hormonereceptor-1A and IGF1 mRNA decreased while IGF binding proteins 1,2,4,5 and 6 (IGFBP) mRNA as well as mRNA expression of insulin, leptin (LEPRb) and adiponectin-2 receptors increased from pre to postpartum in all cows. However, only hepatic IGFBP6 and LEPRb mRNA were greater in $G 2$ than $G 0$ and $G 1$ cows, respectively.

Conclusion: Metabolic-endocrine profiles of cows with different feeding strategies in early lactation reflected not only changes in milk energy output and energy balance but also in walking and grazing activity. Concentrations of insulin and IGF-I were increased in G0 cows whereas plasma adiponectin and both, insulin and leptin sensitivity were improved G2 cows. Increased NE demands in G2 cows when compared to G1 and G0 cows, implied a metabolic stress that impacted negatively on reproductive function.
\end{abstract}

\footnotetext{
*Correspondence: lauaste@gmail.com

1 Department of Animal Production and Pastures, School of Agronomy,

Universidad de la República (UdelaR), Av. E. Garzón 780, C.P.

12900 Montevideo, Uruguay

Full list of author information is available at the end of the article
} 


\section{Background}

Pasture-based dairy production systems have gained interest during the last decade due to their economic, environmental and animal-welfare advantages [1]. However, these production systems do not allow cows to approach their genetic potential for milk production and dry matter intake (DMI), especially in early lactation [2]. Maximizing DMI is crucial for a successful establishment of high lactation as the onset of lactation is accompanied by a period of negative energy balance during which, the high-producing dairy cows mobilize body energy reserves and lose body condition score (BCS) to support the copious amount of milk produced [3, 4].

The transition between late pregnancy and early lactation involves coordination among organs and tissues, including the mammary gland and metabolically active tissues like liver and adipose tissue. This is achievable, among other mechanisms, because the liver becomes refractory to growth hormone $(\mathrm{GH})$ uncoupling the somatotrophic axis. The uncoupling of the GH-IGF axis is associated to a catabolic endocrine state of increased $\mathrm{GH}$ and decreased IGF-I concentrations that, together with low concentrations of insulin, support tissue mobilization, increased liver gluconeogenesis, and high peak milk production $[3,5]$. In addition, adipose tissue plays its role not only in the storage and mobilization of lipids but also as an active endocrine tissue sensing metabolic signals and secreting hormones (i.e. leptin and adiponectin) that affect whole-body energy homeostasis through modulation of glucose and fatty acids metabolism in peripheral tissues, and central regulation of feed intake and energy expenditure [6-8]. Improving nutrition of the postpartum dairy cow will not only impact on milk production but also will minimize the negative effects of the catabolic situation (i.e. IGF-I and insulin) on reproductive performance [9].

In grazing dairy cows, it has been reported that energy intake is the primary determinant of milk production. Thus, most grazing systems incorporate supplementary feeds in the form of forage and concentrates and more recently as mixed rations [10]. Supplementing grazing dairy cows with mixed rations has the potential to capitalize on the benefits of formulated total mixed rations (TMR) while maintaining a relatively low-cost feeding system based on grazed pasture. Previous research has demonstrated that high levels of supplement, as TMR, increased DMI and milk production of grazing dairy cows [10].

Herbage intake in grazing dairy cows is not only limited by physiological and behavioral constraints but also by sward characteristics and grazing management constraints $[10,11]$. Previous reports indicated that daily herbage allowance had a major role in milk production and/or days to first ovulation in supplemented primiparous cows in early lactation, although the very low proportion of the allowed grazing time is spent grazing [9, 12]. Thus, daily access time to pasture and number of grazing sessions could be also used as grazing management tool to improve pasture DMI and milk production, as well as to increase grazing efficiency in dairy cows [11].

The hypothesis of this work was that TMR feeding will result in greater milk production and better reproductive performance than grazing dairy cows, and that the increase of the daily access time at pasture together with the number of grazing sessions during the first 60 days of lactation will maximize pasture DMI and improve energy balance of dairy cows in early lactation. The aim of the present study was to evaluate metabolic and endocrine profiles and hepatic gene expression of Holstein cows fed either TMR ad libitum (without grazing) or diets combining TMR (50\% ad libitum DM intake) and pasture with different grazing strategies $(6 \mathrm{~h}$ in one grazing session or $9 \mathrm{~h}$ in two grazing sessions) in early lactation.

\section{Methods}

The experiment was carried out at the Experimental Station "Dr. Mario A. Cassinoni" of the School of Agronomy (EEMAC, Paysandú, Uruguay) from March to June 2011. Animal procedures were approved by the Animal Experimentation Committee of the Universidad de la República.

\section{Animals and experimental design}

Pluriparous dairy cows $(\mathrm{n}=27$, third-lactation cows, body weight $(\mathrm{BW})=709 \pm 52.5 \mathrm{~kg}, \mathrm{BCS}=3.25 \pm 0.25)$ were used in a complete randomized block design. Cows were grouped according with their expected calving date $(3 / 22 / 11 \pm 2.3$ days $\mathrm{n}=15)$, and $4 / 11 / 114.8$ days, $\mathrm{n}=12$ ) blocked within groups according with $\mathrm{BW}$ and BCS and randomly assigned within block to one of three feeding strategies from calving (day 0 ) to 60 days postpartum (days):control cows fed TMR ad libitum (G0), pasture grazing with $6 \mathrm{~h}$ of access to paddock in one grazing session (8:00-14:00 h) and supplemented with TMR (G1), and pasture grazing with $9 \mathrm{~h}$ of access to paddock in two grazing sessions (8:00-14:00 and 17:00-20:00 h) and supplemented with TMR (G2). Two cows of G2 were removed from the study due to lameness thus the final treatment groups were TMR $(n=9), G 1(n=9)$ and G2 $(\mathrm{n}=7)$.

During the prepartum period (from $-40 \pm 6$ days to calving) the experimental herd was managed to achieve a BCS at calving between 3.0 and 3.5 (1-5 scale; [13]). During this period, a TMR of corn silage and concentrate was fed to the cows to prevent BCS loss. During the postpartum period, all cows were assigned to experimental diets and were offered the same amount of DM (ad libitum, 
approximately $30.7 \mathrm{~kg} \mathrm{DM} / \mathrm{cow} / \mathrm{d}$ ) only as TMR (for G0 cows) or $50 \%$ DM as pasture and $50 \%$ as TMR (for G1 and G2 cows). Cows (G1 and G2) grazed a second year perennial pasture of Festuca arundinacea, Trifolium repens and Lotus corniculatus (located $1.7 \mathrm{~km}$ from the milking parlour) in a $7-\mathrm{d}$ rotational system with a mean herbage allowance of $15 \mathrm{~kg} \mathrm{DM} /$ cow/d $(4 \mathrm{~cm}$ above ground level) with $325 \pm 1.8 \mathrm{~g} / \mathrm{kg}$ of DM, $165 \pm 1 \mathrm{~g} /$ $\mathrm{kg}$ DM of crude protein (CP), $479 \pm 3.1 \mathrm{~g} / \mathrm{kg}$ DM of neutral detergent fiber (NDF), $236 \pm 0.5 \mathrm{~g} / \mathrm{kg} \mathrm{DM}$ of acid detergent fiber (ADF), and $1.6 \mathrm{Mcal} / \mathrm{kg}$ of net energy of lactation (NEL). The TMR, had a forage/concentrate ratio of 45/55 (DM basis) and was composed by corn or sorghum silage and a concentrate that included dry ground corn (19\%), wheat grain (12\%), soybean expeller (9\%), sunflower expeller (11\%), urea (3\%), minerals and vitamins $(9 \%)$ with a chemical composition of $544 \pm 36 \mathrm{~g} / \mathrm{kg}$ of DM, $158 \pm 20 \mathrm{~g} / \mathrm{kg}$ DM of CP, $309 \pm 31 \mathrm{~g} / \mathrm{kg}$ DM of NDF, $165 \pm 16 \mathrm{~g} / \mathrm{kg}$ DM of ADF, and $1.6 \mathrm{Mcal} / \mathrm{kg}$ of NEL. This TMR was formulated according to NRC [14] for a milk production target of $40 \mathrm{~kg} / \mathrm{d}$ and a $15 \%$ feed refusal. The TMR was offered once a day in the afternoon to G1 and G2 cows and twice a day (40\% in the morning and $60 \%$ in the afternoon) to the G0 cows.

The proportion of TMR and pasture in the diet (DM basis) calculated for each treatment after the DM intake of TMR (based on difference between feed offered and refused) and pasture (based on alkane-dosing) was determined, indicated that diet was composed of $27 \%$ pasture and $73 \%$ TMR for G1 cows and $34 \%$ pasture and $66 \%$ TMR for G2 cows [15] Nutrient composition of estimated diets are presented in Table 1.

Cows were milked twice a day (5:00 and 15:00 h), milk production was determined daily and milk samples

Table 1 Estimated nutrient composition of diets according to feeding strategy in early lactation

\begin{tabular}{llll}
\hline Component $^{\mathbf{a}}$ & \multicolumn{2}{l}{ Treatments $^{\mathbf{b}}$} & \\
\cline { 2 - 4 } & G0 & G1 & G2 \\
\hline DM, g/kg & 613 & 532 & 512 \\
CP, g/kg & 156 & 156 & 159 \\
Digestible RUP, \% of DM & 79.5 & 78.0 & 77.7 \\
NDF, g/kg & 336 & 308 & 301 \\
ADF, g/kg & 204 & 216 & 219 \\
Ash, g/kg & 45 & 62 & 66 \\
NEL, Mcal/d & 1.55 & 1.58 & 1.60 \\
\hline
\end{tabular}

a Nutrient composition calculated from TMR and pasture DMI estimated by Fajardo et al. [15] and feed sample chemical analyses

b Feeding strategies from calving (day 0) to 60 days postpartum: GO DM offered as $100 \%$ total mixed ration (TMR; $n=9$ ), G1 DM offered as $50 \%$ pasture in one (am) grazing session ( $6 \mathrm{~h}$ ) plus $50 \%$ TMR $(n=9)$, G2 DM offered as $50 \%$ pasture in two $(\mathrm{am} / \mathrm{pm})$ grazing sessions $(9 \mathrm{~h})+50 \% \operatorname{TMR}(\mathrm{n}=7)$ were obtained weekly to determine fat, protein and lactose composition. Cow BCS and BW were measured weekly and blood samples were obtained weekly from -40 to +60 days immediately after the morning milking by venipuncture of the coccygeal vein in heparinized tubes. Samples were centrifuged $(2000 \times g$ for $15 \mathrm{~min}$ at $4{ }^{\circ} \mathrm{C}$ ) within $2 \mathrm{~h}$ after collection and plasma was stored at $-20{ }^{\circ} \mathrm{C}$ until assayed. Liver biopsies were obtained from cows at $-40 \pm 6,-20 \pm 3,+10 \pm 4$ and $+55 \pm 4$ days using a 14-gauge biopsy needle (Tru-Core ${ }^{\circledR}$-II Automatic Biopsy Instrument; Angiotech, Lausanne, Switzerland) as described by Carriquiry et al. [16]. Liver samples were immediately frozen in liquid nitrogen and stored at $-80^{\circ} \mathrm{C}$ until total RNA was isolated.

\section{Metabolite and hormone analyses}

The metabolic profiles (non-esterified fatty acids(NEFA), $\beta$-hydroxybutyrate (BHB), glucose and urea) were determined by colorimetric assays on Vitalab Selectra II autoanalyzer (Vital Scientific, Dieren, The Netherlands) using commercial kits (Wako NEFA-HR(2), Wako Pure Chemical Industries Ltd., Osaka, Japan for NEFA; Randox Laboratories Limited, 55 Diamond Road, Crumlin, Country Antrim, BT29 4QY, United Kingdom for BHB; Wiener Laboratories S.A.I.C. Riobamba, Rosario, Argentina for glucose and urea). All samples were determined in the same assay for each metabolite, the intra-assay $\mathrm{CV}$ for all determinations was less or equal than $10 \%$.

Concentrations of insulin and IGF-I were measured using immunoradiometric assays (IRMA) with commercial kits (INS-IRMA; DIA Source Immune Assays S.A., Belgium and IGF-I-RIACT Cis Bio International, GIF-SUR-YVETTE CEDEX, France, respectively) previously used in bovine [17]. All samples were determined in a single assay for each hormone. For insulin, the assay detection limit was $0.7 \mu \mathrm{IU} / \mathrm{ml}$, and intra-assay $\mathrm{CV}$ for control $1(22.3 \mu \mathrm{IU} / \mathrm{ml})$ and $2(55.5 \mu \mathrm{IU} / \mathrm{ml})$ were 8.2 and $8.3 \%$, respectively. For IGF-I, the assay detection limit was $0.3 \mathrm{ng} / \mathrm{ml}$, and intra-assay CV for control 1 (41.1 ng/ $\mathrm{ml})$ and control $2(521.5 \mathrm{ng} / \mathrm{ml})$ were 7.8 and $7.9 \%$, respectively.

Leptin concentrations were determined by a liquidphase radioimmunoassay (RIA) using a commercial Multi-Species Leptin kit (RIA kit, Millipore, USA) previously reported in bovines $[17,18]$. The RIA had a sensitivity of $2.9 \mathrm{ng} / \mathrm{ml}$. All samples were determined in the same assay and the intra-assay CV for control 1 (4.2 ng/ $\mathrm{ml})$ and control $2(18.8 \mathrm{ng} / \mathrm{ml})$ were 8.2 and $7.4 \%$, respectively. In the absence of purified bovine adiponectin, concentrations of adiponectin were measured with a human RIA kit (HADP-61 HK, Millipore, USA) using undiluted plasma samples $[18,19]$. The sensitivity of the assay was $1.54 \mathrm{ng} / \mathrm{ml}$. All samples were determined in the same 
assay and the intra-assay CV for control $1(12.2 \mathrm{ng} / \mathrm{ml})$ and control $2(95.4 \mathrm{ng} / \mathrm{ml})$ were 6 and $12 \%$, respectively.

Days to first ovulation were determined by progesterone milk concentrations twice a week. Milk was skimmed at $3000 \mathrm{rpm}$ at $4{ }^{\circ} \mathrm{C}$ for $15 \mathrm{~min}$. Progesterone concentrations in skim milk were measured by a solid-phase RIA using a commercial kit (Coat and Count; Diagnostic Products, Los Angeles, CA, USA). All samples were analyzed in a single assay; the sensitivity was $0.01 \mathrm{ng} / \mathrm{ml}$, the intra-assay $\mathrm{CV}$ was not greater than $10.6 \%$. Days to first ovulation was defined as the day in which progesterone concentration in milk had two consecutive samples greater than $1 \mathrm{nmol} / \mathrm{l}$.

\section{Isolation and purification of RNA}

Isolation of total RNA from hepatic tissue and synthesis of cDNA by reverse transcription was performed according with Carriquiry et al. [16] (see Additional file 1). Primers (Additional file 1) to specifically amplify cDNA of target genes: GHR, GHR1A, IGF1, IGF2, IGF binding proteins-1 to 6 (IGFBP1, IGFBP2, IGFBP3, IGFBP4, IGFBP5, IGFBP6), insulin receptor (INSR), long form of the leptin receptor $(L E P R b)$, adiponectin receptor 1 and 2 (ADIPOR1, ADIPOR2), and from endogenous controls: $\beta$-actin (ACTB), hypoxanthine phosphoribosyltransferase (HPRT), and ribosomal protein S9 (RPS9), were obtained from literature or specifically designed using the Primer3 website (http://frodo.wi.mit.edu/primer3/) based on bovine nucleotide sequences available from NCBI (http://www.ncbi.nlm.nih.gov/). Before use, primer product sizes ( $1 \%$ agarose gel separation) and sequences (Macrogen Inc., Seoul, Korea) were determined to ensure that primers produced the desired amplicons.

Real time PCR reactions were performed in a total volume of $15 \mu \mathrm{l}$ using KAPA SYBR ${ }^{\circledR}$ FAST Universal 2X qPCR Master Mix (Kapa Biosystems, inc. Woburn, MA, USA) according with Astessiano et al. [20]. using the following standard amplification conditions: $10 \mathrm{~min}$ at $95{ }^{\circ} \mathrm{C}$ and 40 cycles of $15 \mathrm{~s}$ at $95^{\circ} \mathrm{C}, 45 \mathrm{~s}$ at $60{ }^{\circ} \mathrm{C}$, and $20 \mathrm{~s}$ at $72{ }^{\circ} \mathrm{C}$. Dissociation curves were run on all samples to detect primer dimers, contamination, or presence of other amplicons. Each disk included a pool of total RNA from bovine liver samples analyzed in triplicate to be used as the basis for the comparative expression results (exogenous control) and duplicate tubes of water (non-template control). Gene expression was measured by relative quantification [21] to the exogenous control and normalized to the geometric mean expression of the endogenous control genes (HPRT, ACTB and RPS9). Expression stability of 3 selected housekeeping genes was evaluated using MS-Excel add-in Normfinder (MDL, Aarhus, Denmark). The stability values obtained with Normfinder they were $0.144,0.121$, and 0.178 for
$H P R T, A C T B$, and RPS9, respectively. Amplification efficiencies or target and endogenous control genes were estimated by linear regression of a dilution cDNA curve $(\mathrm{n}=5$ dilutions, from 100 to $6.25 \mathrm{ng} /$ tube; Additional file 1). Intra and inter-assay CV values were 1.9 and $4.2 \%$, respectively.

\section{Calculations and statistical analyses}

Net energy (NE) and metabolizable protein (MP) calculations were based on NRC [14]. Maintenance $\mathrm{NE}$ requirements were calculated as NEM $=0.08 \times$ $\mathrm{BW}^{0.75}+$ NEmact, where NEmact $=((($ Distance $/ 1000) \times$ Trips $) \times(0.00045 \times \mathrm{BW}))+(0.0012 \times(\mathrm{BW}))$. Lactation NE requirements were calculated as NEL $=$ milk yield $\times[(0.0929 \times$ fat $\%)+(0.0563 \times$ true protein $\%)+(0.0395 \times$ lactose \%)], using composition data derived from analysis of samples collected weekly. Metabolizable protein required for maintenance was calculated as $\mathrm{MPM}=4.1 \times\left(\mathrm{BW}^{0.50}\right)+0.30 \times(\mathrm{BW}$ $\left.{ }^{0.60}\right)+((\mathrm{DMI} \times 30)-[0.50 \times($ bacterial MP/0.8) $]-$ bacterial MP) + endogenous MP/0.67. Metabolizable protein required for lactation (MPL) was calculated as $\mathrm{MPL}=($ milk yield $\times$ true protein $\%) / 0.67$.

Estimation of the revised quantitative insulin sensitivity check index (RQUICKI) was done according to Perseghin et al. [22], i.e. RQUICKI $=1 /[\log ($ Glucose, $\mathrm{mg} / \mathrm{dl})+\log ($ Insulin, $\mu \mathrm{U} / \mathrm{ml})+\log (\mathrm{NEFA}, \mathrm{mmol} / \mathrm{l})]$, in which a low RQUICKI index indicates decreased insulin sensitivity.

Data were analyzed in a randomized block design using the SAS System program (SAS Institute Inc., Cary, NC, USA). Univariate analyses were performed on all variables to identify outliers and inconsistencies and to verify normality of residuals. Data of BCS, energy and MP balances and their components, plasma metabolite and hormone concentrations and hepatic mRNA expression were analyzed by repeated measures using the MIXED procedure with days postpartum as the repeated effect, and the appropriate covariance structure [first-order autoregressive $(\mathrm{AR}(1))$ for evenly spaced data or spatial power $(\mathrm{SP}(\mathrm{POW}))$ for unevenly spaced data]. The Kenward-Rogers procedure was used to adjust the denominator degree of freedom. Data were analyzed with a model that included period (pre or postpartum), nutritional treatment within period (no treatment for period prepartum and G1, G2 and G0 for period post partum), days postpartum within period, and the interaction between treatment and days within period as fixed effects and replication and block within replication as random effects. The interaction between treatment and replication was included in the model as a random effect but as covariance parameter estimates were zero or close to zero it was removed from the model. 
Days to first ovulation was defined as the number of days from calving to reinitiation of ovarian cyclicity. The probability for first ovulation was estimated by the proportion of cows with first ovulation confirmed every 5 days from day 15 to 60 postpartum. Days to first ovulation and probability of cows cycling during the first month were analyzed with a generalized lineal model using the GENMOD procedure with a model that included the fixed effect of nutritional treatment and with the Poisson and a log link or binomial distribution and a logit link specified, respectively. Tukey-Kramer tests were conducted to analyze differences between groups $(\alpha=0.05)$. For all results, means were considered to differ when $P \leq 0.05$, and trends were identified when $0.05<P \leq 0.10$. Data are presented as least square means \pm pooled standard errors.

\section{Results}

\section{Cow productive and reproductive performance}

Milk energy output tended $(P=0.09)$ to be greater for G0 than G1 cows but not for G2 cows (Table 2; Fig. 1a), whereas, estimated NEM during the first 60 days was the greatest $(P<0.05)$ for $\mathrm{G} 2$ and the lowest for $\mathrm{G} 0$ cows due to differences in NE requirement for waking and grazing activity. In contrast, milk MP requirement did not differ among treatments (Table 2). However, both estimated NEL and MP balances were greater $(P=0.01)$ for $\mathrm{G0}$ than $\mathrm{G} 1$ and $\mathrm{G} 2$ cows.

Cow BCS decreased $(P<0.05)$ from -20 to +55 days and at +55 days was greater $(P<0.05)$ in G0 than G2 cows (Table 2; Fig. 1b). Days to first ovulation were greater $(P=0.02)$ for $\mathrm{G} 2$ than $\mathrm{G} 1$ cows and intermediate for G0 (21, 40 and $28 \pm 5$ days for G1, G2 and G0, respectively) while probability of cows cycling during the first month of lactation was greater $(P<0.01)$ for $\mathrm{G} 0$ and G1 than G2 cows $(89,43$ and $71 \%$ for G1, G2 and G0, respectively) (Fig. 1c).

\section{Plasma metabolites and hormones}

Concentrations of NEFA peaked between +5 and +12 days and during the postpartum were greater $(P=0.02)$ in G1 than G2 and G0 cows, as NEFA concentrations remained elevated at +30 and +40 days only in former ones (Fig. 2a). Concentrations of BHB peaked between +15 and +30 days and during the postpartum were greater $(P<0.05)$ in G1 and G2 than G0 cows (Fig. 2b). Plasma glucose and urea were not affected by treatment, but varied during the transition and early lactation periods. Plasma glucose concentrations increased $(P<0.01)$ from calving to +55 days, while plasma urea concentrations decreased $(P<0.01)$ from -40 to calving and then increased $(P<0.01)$ until +55 days (data not shown).
Table 2 Effect of early feeding strategy on cow BW, BCS, and estimated net energy of lactation (NEL) and metabolizable protein (MP) balances

\begin{tabular}{llllll}
\hline Variable & \multicolumn{2}{l}{ Treatments $^{\mathbf{1}}$} & & SE & P value \\
\cline { 2 - 4 } & G0 & G1 & G2 & & \\
\hline Estimated NEL balance & & & & & \\
Maintenance, Mcal of/d & $10.3^{\mathrm{c}}$ & $12.8^{\mathrm{b}}$ & $13.9^{\mathrm{a}}$ & 0.03 & 0.01 \\
Milk, Mcal/d & $27.8^{\mathrm{x}}$ & $24.0^{\mathrm{y}}$ & $26.5^{\mathrm{xy}}$ & 1.25 & 0.09 \\
Balance, Mcal/d & $2.7^{\mathrm{a}}$ & $-5.2^{\mathrm{b}}$ & $-5.6^{\mathrm{b}}$ & 1.30 & 0.01 \\
Estimated MP balance & & & & & \\
Milk, g of MP/d & 1780 & 1620 & 1660 & 70.24 & 0.30 \\
Balance, g of MP/d & $0.08^{\mathrm{a}}$ & $-0.26^{\mathrm{b}}$ & $-0.34^{\mathrm{b}}$ & 0.08 & 0.01 \\
BW, kg & 646 & 655 & 618 & 15 & 0.23 \\
BCS, units & 2.9 & 2.8 & 2.8 & 0.07 & 0.53
\end{tabular}

1 Feeding strategies from calving (day 0 ) to 60 days postpartum: DM offered as $100 \%$ total mixed ration (TMR; $n=9$ ), G1 DM offered as $50 \%$ pasture in one (am) grazing session $(6 \mathrm{~h})$ plus $50 \%$ TMR $(n=9), G 2 \mathrm{DM}$ offered as $50 \%$ pasture in two $(\mathrm{am} / \mathrm{pm})$ grazing sessions $(9 \mathrm{~h})+50 \%$ TMR $(\mathrm{n}=7)$

2 Required NEL and MP for maintenance (including NEL for activity) and milk, values were calculated according to NRC [14]

$\mathrm{a}, \mathrm{b}, \mathrm{c}$ Letters denote least squares means $\operatorname{differ}(P \leq 0.05)$

xy Indicate a tendency $0.05<P>0.10$, for the interaction between cow groups and treatments

Plasma insulin concentrations decreased $(P=0.02)$ around calving and during the postpartum period were greater $(P=0.02)$ in $\mathrm{G} 0$ than $\mathrm{G} 2$ cows (Fig. $2 \mathrm{c}$ ). Plasma IGF-I concentrations decreased $(P<0.01)$ from -40 to +5 days and increased thereafter until +55 days, but prepartum concentrations were not recovered at the end of the experimental period, and during the postpartum period tended to be greater $(P=0.06)$ in $\mathrm{G} 0$ and $\mathrm{G} 1$ than $\mathrm{G} 2$ cows (Fig. 2d). Leptin concentrations decreased $(P<0.01)$ from -40 days to calving, increasing thereafter and during the postpartum were greater $(P<0.01)$ in G2 and G0 than G1 cows (Fig. 2e). Adiponectin concentrations increased $(P<0.01)$ from pre to postpartum and during the postpartum were greater $(P=0.01)$ in G2 than G1 and G0 cows as plasma adiponectin were elevated at +15 and +30 days only in the former ones (Fig. 2f). However, the adiponectin to leptin ratio was not affected by treatment or days of lactation (averaged 95.6, $83.3,70.0 \pm 24.4$ for G1, G2 and G0 cows, respectively). The RQUICKI index decreased $(P<0.01)$ from -40 days to calving, and during the postpartum was greater $(P=0.02)$ in $\mathrm{G} 2$ than $\mathrm{G} 1$ and intermediate in G0 cows.

\section{Hepatic gene expression}

Hepatic GHR mRNA was not affected by period, but tended to be affected by treatment $(P=0.09)$ being 1.8-fold greater in G1 than G2 cows during the postpartum (Table 3). However, expression of GHR1A 

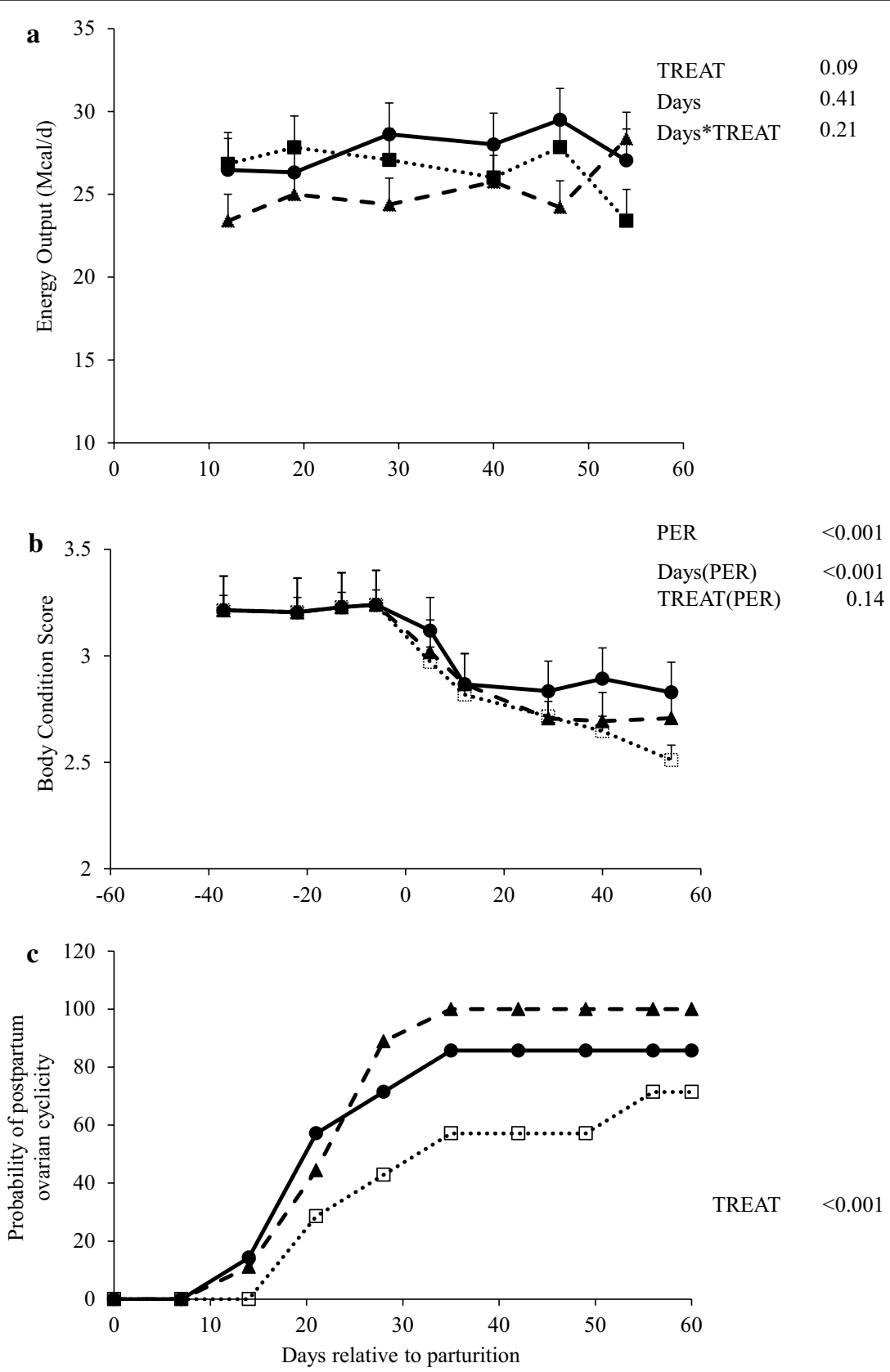

Fig. 1 Productive responses (BCS and milk yield, (a) and (b), respectively) and probability of days to first ovulation (c) during peripartum and early lactation period (from -40 to 55 days relative to parturition) in pluriparous dairy cows assigned to three different feeding strategies during the postpartum. From calving (day 0) to 60 days postpartum: G0 DM offered as $100 \%$ total mixed ration (TMR; $n=9$; solid line), G1 DM offered as $50 \%$ pasture in one (am) grazing session ( $6 \mathrm{~h}$ ) plus $50 \%$ TMR ( $\mathrm{n}=9$; dash line), and G2 DM offered as $50 \%$ pasture in two (am/pm) grazing sessions $(9 h)+50 \%$ TMR $(n=7$; dotted line). Differences between cow groups are indicated with * when $P \leq 0.05 . T$ treatment, Days day of lactation

decreased $(P<0.01)$ and IGF1 mRNA tended to decrease $(P=0.08)$ from pre to postpartum while IGF2 mRNA increased $(P=0.002)$ at +55 days for all cows (Table 3$)$. Hepatic IGFBP1, IGFBP4 and IGFBP5 mRNA increased $(P \leq 0.04)$ from pre to postpartum while IGFBP2 mRNA increased $(P<0.01)$ from -20 vs. +10 days and tended to decrease again $(P=0.06)$ at +55 days (Table 3$)$. In contrast, IGFBP3 mRNA tended $(P=0.08)$ to increase from -40 to -20 days and decreased $(P<0.01)$ from -20 to +10 days (Table 3). Expression of IGFBP6 mRNA tended $(P=0.07)$ to increase from pre to postpartum and to be affected by treatment, being greater in G2 than 


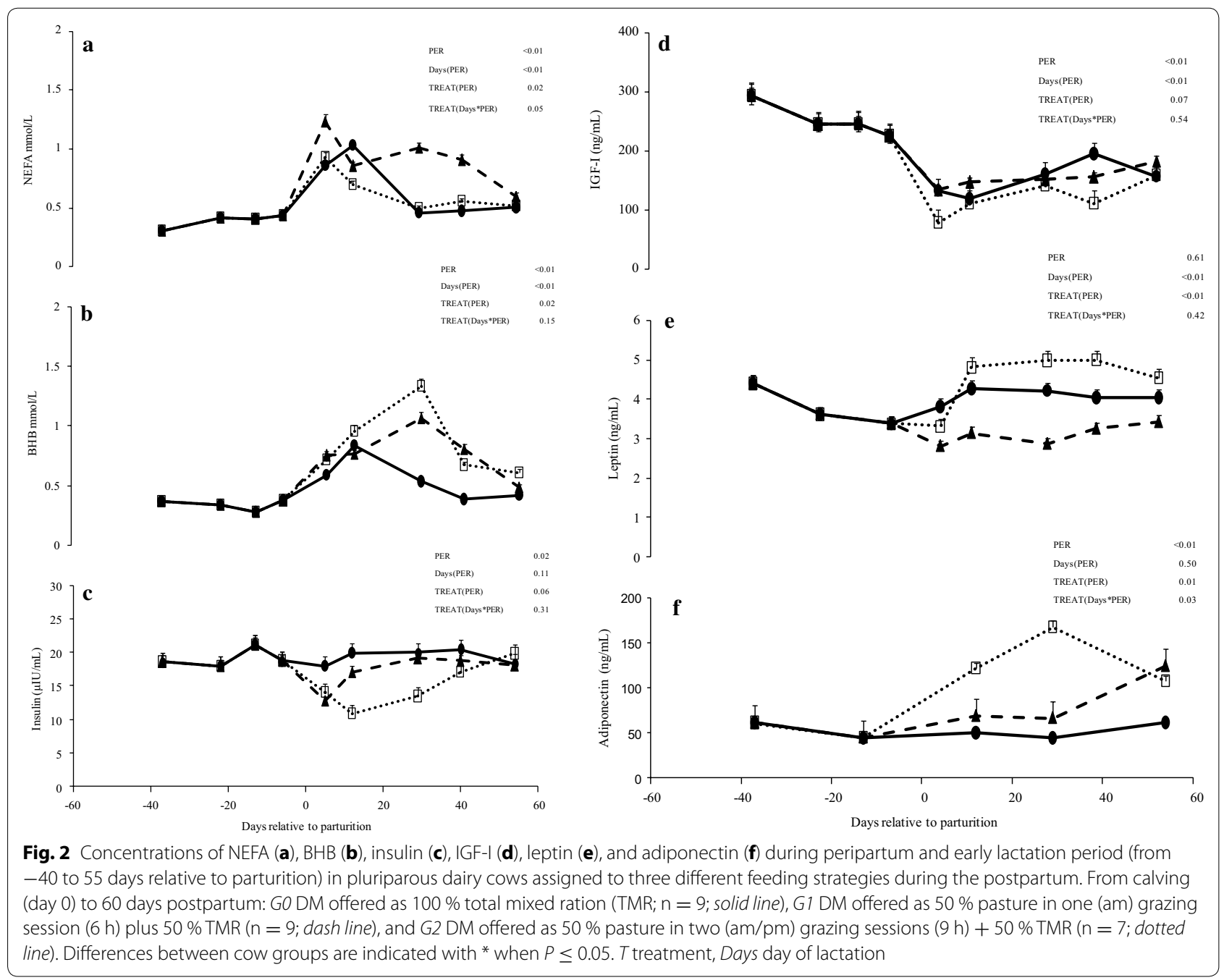

G0 and intermediate in G1 cows during the postpartum (Table 3).

Expression of INSR mRNA in the liver increased $(P<0.03)$ at +55 days for all cows (Table 4$)$. Hepatic $L E P R b$ mRNA increased $(P<0.01)$ from pre to postpartum and was greater $(P<0.05)$ in $\mathrm{G} 2$ than G1 cows during early lactation (Table 4). Although ADIPOR1 mRNA did not vary due to feeding strategies or days of lactation, ADIPOR2 mRNA increased $(P<0.01)$ from pre to postpartum in all cows (Table 4 ).

\section{Discussion}

Days of lactation on metabolic and endocrine profiles and liver gene expression

During the peripartum and early lactation, all cows entered a period of negative energy balance, as the rapid increase in milk yield was not met by DMI, determining various metabolic and endocrine adaptations to provide energy and nutrients to the early lactating mammary gland [3]. Cows mobilized body reserves, reflected by the loss of $\mathrm{BCS}$ and the elevated plasma concentrations of NEFA and BHB in blood that indicated increased lipolysis and ketogenesis [4, 9]. In addition, plasma urea decreased around calving and increased during early lactation probably, reflecting enhanced tissue protein breakdown to provide gluconeogenesis precursors as well as the increase feed intake [23].Insulin and IGF-I concentrations decreased around calving which was consistent with the reduction in DMI, characteristic of this period and with an uncoupled somatotropic axis, which mediates nutrient partitioning towards milk production [3, 5]. Indeed, the IGF-I decrease at calving was associated with GHR1A and IGF1 mRNA decreases during the early postpartum while no changes were detected in the abundance of hepatic GHR mRNA as reported before [24]. Decreased insulin concentrations are hypothesized to 
Table 3 Hepatic expression of genes related to the GH-IGF axis during the peripartum and early lactation periods (from $\mathbf{- 4 0}$ to $\mathbf{5 5}$ days relative to parturition) of dairy cows assigned to three different feeding strategies during the first 60 days of lactation

\begin{tabular}{|c|c|c|c|c|c|c|c|c|c|}
\hline \multirow[t]{2}{*}{ Gene $^{3}$} & \multirow[t]{2}{*}{ Days } & \multirow[t]{2}{*}{$\mathrm{All}^{4}$} & \multicolumn{3}{|c|}{ Treatments $^{1}$} & \multirow[t]{2}{*}{ SE } & \multicolumn{3}{|c|}{ P value $^{2}$} \\
\hline & & & G0 & G1 & G2 & & PER & Days (PER) & TREAT (PER) \\
\hline \multirow[t]{5}{*}{ GHR } & & & & & & & 0.39 & 0.27 & 0.09 \\
\hline & -40 & 1.00 & - & - & - & - & & & \\
\hline & -20 & 0.88 & - & - & - & - & & & \\
\hline & 10 & 0.75 & $0.78^{\mathrm{ab}}$ & $0.91^{\mathrm{ab}}$ & $0.56^{\mathrm{b}}$ & 0.57 & & & \\
\hline & 55 & 1.01 & $0.88^{\mathrm{ab}}$ & $1.47^{\mathrm{a}}$ & $0.69^{b}$ & 0.56 & & & \\
\hline \multirow[t]{5}{*}{ GHR1A } & & & & & & & $<0.01$ & 0.10 & 0.97 \\
\hline & -40 & $1.00^{\mathrm{a}}$ & - & - & - & - & & & \\
\hline & -20 & $0.91^{\mathrm{a}}$ & - & - & - & - & & & \\
\hline & 10 & $0.56^{\mathrm{b}}$ & 0.58 & 0.58 & 0.51 & 0.19 & & & \\
\hline & 55 & $0.41^{c}$ & 0.42 & 0.40 & 0.41 & 0.18 & & & \\
\hline \multirow[t]{5}{*}{ IGF1 } & & & & & & & 0.08 & 0.70 & 0.20 \\
\hline & -40 & $1.02^{x y}$ & - & - & - & - & & & \\
\hline & -20 & $1.12^{x}$ & - & - & - & - & & & \\
\hline & 10 & $0.84^{y}$ & 0.58 & 0.79 & 1.17 & 0.32 & & & \\
\hline & 55 & $0.92^{x y}$ & 0.74 & 1.11 & 0.91 & 0.31 & & & \\
\hline \multirow[t]{5}{*}{ IGF2 } & & & & & & & $<0.01$ & 0.05 & 0.91 \\
\hline & -40 & $1.00^{\mathrm{b}}$ & - & - & - & - & & & \\
\hline & -20 & $1.20^{\mathrm{b}}$ & - & - & - & - & & & \\
\hline & 10 & $1.29^{b}$ & 1.20 & 1.27 & 1.39 & 0.43 & & & \\
\hline & 55 & $1.76^{\mathrm{a}}$ & 1.80 & 1.98 & 1.51 & 0.48 & & & \\
\hline \multirow[t]{5}{*}{$|G F B P|$} & & & & & & & $<0.01$ & 0.42 & 0.25 \\
\hline & -40 & $1.00^{\mathrm{b}}$ & - & - & - & - & & & \\
\hline & -20 & $1.15^{\mathrm{b}}$ & - & - & - & - & & & \\
\hline & 10 & $1.96^{\mathrm{a}}$ & 2.09 & 1.56 & 2.25 & 0.93 & & & \\
\hline & 55 & $2.44^{\mathrm{a}}$ & 3.25 & 1.85 & 2.20 & 0.97 & & & \\
\hline \multirow[t]{5}{*}{ IGFBP2 } & & & & & & & $<0.01$ & 0.10 & 0.94 \\
\hline & -40 & $1.00^{\mathrm{b}}$ & - & - & - & - & & & \\
\hline & -20 & $1.24^{\mathrm{b}}$ & - & - & - & - & & & \\
\hline & 10 & $3.35^{\mathrm{a}}$ & 3.46 & 3.20 & 3.38 & 0.79 & & & \\
\hline & 55 & $2.43^{\mathrm{a}}$ & 2.25 & 2.78 & 2.26 & 0.81 & & & \\
\hline \multirow[t]{5}{*}{ IGFBP3 } & & & & & & & 0.09 & 0.10 & 0.54 \\
\hline & -40 & $1.00^{\mathrm{ab}}$ & - & - & - & - & & & \\
\hline & -20 & $1.25^{\mathrm{a}}$ & - & - & - & - & & & \\
\hline & 10 & $0.91^{b}$ & 1.10 & 0.74 & 0.90 & 0.24 & & & \\
\hline & 55 & $1.05^{\mathrm{ab}}$ & 1.00 & 1.04 & 1.10 & 0.24 & & & \\
\hline \multirow[t]{5}{*}{ IGFBP4 } & & & & & & & 0.04 & 0.54 & 0.73 \\
\hline & -40 & $1.00^{\mathrm{ab}}$ & - & - & - & - & & & \\
\hline & -20 & $0.97^{b}$ & - & - & - & - & & & \\
\hline & 10 & $1.14^{\mathrm{ab}}$ & 1.05 & 1.04 & 1.32 & 0.41 & & & \\
\hline & 55 & $1.35^{\mathrm{a}}$ & 1.25 & 1.34 & 1.45 & 0.40 & & & \\
\hline \multirow[t]{5}{*}{ IGFBP5 } & & & & & & & $<0.01$ & 0.62 & 0.74 \\
\hline & -40 & $1.00^{b}$ & - & - & - & - & & & \\
\hline & -20 & $1.10^{\mathrm{b}}$ & - & - & - & - & & & \\
\hline & 10 & $2.03^{\mathrm{a}}$ & 2.09 & 1.60 & 2.41 & 0.84 & & & \\
\hline & 55 & $1.75^{\mathrm{a}}$ & 1.36 & 2.03 & 1.85 & 0.94 & & & \\
\hline
\end{tabular}


Table 3 continued

\begin{tabular}{|c|c|c|c|c|c|c|c|c|c|}
\hline \multirow[t]{2}{*}{ Gene $^{3}$} & \multirow[t]{2}{*}{ Days } & \multirow[t]{2}{*}{$\mathrm{All}^{4}$} & \multicolumn{3}{|c|}{ Treatments $^{1}$} & \multirow[t]{2}{*}{ SE } & \multicolumn{3}{|c|}{ P value $^{2}$} \\
\hline & & & G0 & G1 & G2 & & PER & Days (PER) & TREAT (PER) \\
\hline \multirow[t]{5}{*}{ IGFBP6 } & & & & & & & 0.08 & 0.71 & 0.06 \\
\hline & -40 & $1.00^{y}$ & - & - & - & - & & & \\
\hline & -20 & $0.97^{y}$ & - & - & - & - & & & \\
\hline & 10 & $1.13^{x y}$ & $0.93^{b}$ & $1.01^{\mathrm{ab}}$ & $1.46^{\mathrm{ab}}$ & 0.34 & & & \\
\hline & 55 & $1.29^{x}$ & $0.86^{b}$ & $1.33^{\mathrm{ab}}$ & $1.68^{\mathrm{a}}$ & 0.34 & & & \\
\hline
\end{tabular}

1 Feeding strategies from calving (day 0 ) to 60 days postpartum: G0 DM offered as $100 \%$ total mixed ration (TMR; $\mathrm{n}=9$ ), G1 DM offered as $50 \%$ pasture in one (am) grazing session (6 h) plus $50 \%$ TMR $(n=9)$, G2 DM offered as $50 \%$ pasture in two $(\mathrm{am} / \mathrm{pm})$ grazing sessions $(9 \mathrm{~h})+50 \%$ TMR $(\mathrm{n}=7)$

2 PER period (pre vs. postpartum), TREAT treatment. The interaction TREAT (PER) $\times$ Days was not significant $(P>0.25)$ for any of the genes

${ }^{3}$ GHR = growth hormone receptor, GHR1A = growth hormone receptor $1 \mathrm{~A}$, IGF1 = insulin-like growth factor-I, IGF2 = insulin-like growth factor-2, IGFBP = IGF-

binding protein 1 to 6 . Relative units, data are expressed as fold difference relative to first sample ( -40 days)

${ }^{4}$ Lsmeans for Days(PER) effect, including all treatments

$\mathrm{a}, \mathrm{b}, \mathrm{c}$ Letters denote least squares means differ $(P \leq 0.05)$

xy Indicate a tendency $0.05<P>0.10$, according to Tukey-Kramer test for the interaction between PER, Days and TREAT

Table 4 Hepatic expression of genes related to the energy metabolism during the peripartum and early lactation periods (from $-\mathbf{4 0}$ to 55 days relative to parturition) in multiparous dairy cows assigned to three different feeding strategies during the first 60 days of lactation

\begin{tabular}{|c|c|c|c|c|c|c|c|c|c|}
\hline \multirow[t]{2}{*}{ Gene $^{3}$} & \multirow[t]{2}{*}{ Days } & \multirow[t]{2}{*}{ All ${ }^{4}$} & \multicolumn{3}{|c|}{ Treatments $^{1}$} & \multirow[t]{2}{*}{ SE } & \multicolumn{3}{|c|}{ P value $^{2}$} \\
\hline & & & Go & G1 & G2 & & PER & Days (PER) & TREAT (PER) \\
\hline \multirow[t]{5}{*}{ INSR } & & & & & & & $<0.01$ & 0.04 & 0.92 \\
\hline & -40 & $1.00^{b}$ & - & - & - & - & & & \\
\hline & -20 & $0.91^{b}$ & - & - & - & - & & & \\
\hline & 10 & $1.12^{\mathrm{ab}}$ & 1.21 & 1.00 & 1.14 & 0.25 & & & \\
\hline & 55 & $1.55^{\mathrm{a}}$ & 1.42 & 1.84 & 1.39 & 0.24 & & & \\
\hline \multirow[t]{5}{*}{ LEPRB } & & & & & & & $<0.01$ & 0.15 & 0.02 \\
\hline & -40 & $1.00^{\mathrm{b}}$ & - & - & - & - & & & \\
\hline & -20 & $1.41^{\mathrm{ab}}$ & - & - & - & - & & & \\
\hline & 10 & $1.49^{\mathrm{a}}$ & $1.61^{a b c}$ & $1.05^{c}$ & $1.80^{\mathrm{ab}}$ & 0.47 & & & \\
\hline & 55 & $1.58^{\mathrm{a}}$ & $1.55^{a b c}$ & $1.17^{b c}$ & $2.03^{\mathrm{a}}$ & 0.48 & & & \\
\hline \multirow[t]{5}{*}{ ADIPOR1 } & & & & & & & 0.33 & 0.40 & 0.99 \\
\hline & -40 & 1.00 & - & - & - & - & & & \\
\hline & -20 & 0.95 & - & - & - & - & & & \\
\hline & 10 & 0.98 & 0.98 & 0.96 & 1.00 & 0.67 & & & \\
\hline & 55 & 1.16 & 1.15 & 1.18 & 1.14 & 0.72 & & & \\
\hline \multirow[t]{5}{*}{ ADIPOR2 } & & & & & & & $<0.01$ & 0.59 & 0.91 \\
\hline & -40 & $1.02^{b}$ & - & - & - & - & & & \\
\hline & -20 & $0.92^{b}$ & - & - & - & - & & & \\
\hline & 10 & $2.27^{a}$ & 2.38 & 2.31 & 2.10 & 0.30 & & & \\
\hline & 55 & $2.06^{a}$ & 1.83 & 2.26 & 2.09 & 0.30 & & & \\
\hline
\end{tabular}

\footnotetext{
${ }^{1}$ Feeding strategies from calving (day 0 ) to 60 days postpartum: G0 DM offered as $100 \%$ total mixed ration (TMR; $\mathrm{n}=9$ ), G1 DM offered as $50 \%$ pasture in one (am) grazing session ( $6 \mathrm{~h})$ plus $50 \%$ TMR $(\mathrm{n}=9), \mathrm{G} 2 \mathrm{DM}$ offered as $50 \%$ pasture in two $(\mathrm{am} / \mathrm{pm})$ grazing sessions $(9 \mathrm{~h})+50 \%$ TMR $(\mathrm{n}=7)$

2 PER period (pre vs. postpartum), TREAT treatment. The interaction TREAT(PER) $\times$ Days was not significant $(P>0.25)$ for any of the genes

${ }^{3} I N S R=$ insulin receptor, $L E P R B=$ full-length leptin receptor, $A D I P O R 1=$ adiponectin receptor $1, A D I P O R 2=$ adiponectin receptor 2 . Relative units, data are expressed as fold difference relative to first sample ( -40 days)

${ }^{4}$ Lsmeans for Days (PER) effect, including all treatments

$\mathrm{a}, \mathrm{b}, \mathrm{c}$ Letters denote least squares means differ $(P \leq 0.05)$
} 
be a key signal regulating this mechanism, as stimulates hepatic IGF-I secretion by modifying hepatic GHR and IGFBP secretion [25].

Most IGF-I is bound to IGFBP3 in a ternary complex, the negative energy balance would induce a shift of this complex to binary complexes in which IGF-I is bound to IGFBP1 and particularly to IGFBP2, which would in turn reduce half-life of IGF-I in blood [26]. The increased hepatic IGFBP1 and IGFBP2 mRNA expression and the simultaneous decrease of IGFBP3 mRNA in all cows have been shown before [20,27] and support this hypothesis. Indeed, Kessler et al. [28], demonstrated that as plasma IGF-I concentrations dropped during the lactation negative energy balance or during feed restriction, binding affinity of IGF-I to IGFBP1 and IGFBP2 in plasma increased while its binding affinity to IGFBP3 decreased, Moreover, IGFBP4 and IGFBP5 mRNA also increased during the postpartum (at +55 and +10 DPP, respectively) and it has been reported that these proteins may have also inhibitory effects on IGF-I activity [29, 30]. On the other hand, in the present study, IGF-I concentrations started to increase after the first month postpartum while GHR1A mRNA expression remained low and hepatic mRNA of low molecular weight IGFBP were still elevated, thus, other factors would be responsible for the increasing IGF-I concentrations during the second month after calving.

Interestingly, hepatic IGF2 and IGFBP6 mRNAs, a binding protein with high affinity to IGF-II, were low during peripartum and increased at +55 days for all cows. Relatively few studies have examined IGF-II during the transition period of the dairy cow, although its transcript is expressed at comparatively high levels in the liver [31]. The greater expression of IGF2, IGFBP6 and also IGFBP4 mRNA together with the greater probability of cycling after the first month postpartum is consistent a role of these genes in reproduction [32-34].

The reduced insulin and elevated NEFA concentrations during the early postpartum, determined that the in the present study RQUICKI decreased during this period, which is indicative of increased reduced insulin resistance [35]. Indeed, the adipokines adiponectin and leptin, are considered positive regulators of insulin sensitivity in various species [6,7]. Reduced concentrations of these hormones around calving, as reported here, may increased insulin resistance of peripheral tissues, which would decrease glucose uptake by skeletal muscles and adipose tissues and increase hepatic gluconeogenesis [7], improving glucose supply to the mammary gland for enhanced milk production. Although adiponectin and leptin profiles during early postpartum period depended of the treatment (see "Discussion" below), the concentrations increased rapidly during the early postpartum.
Similar findings were reported for adiponectin [36], but not for leptin [6]. Differences in leptin profiles during the postpartum between this and other reports could be the result of the restricted feeding dry period nutrition (vs. ad libitum) in the present study. In addition, Weber et al. [37] reported elevated leptin concentrations in dairy cows with moderate hepatic lipid fat associated with reduced abdominal fat mobilization, and in agreement with our results, with reduced insulin and NEFA concentrations and greater insulin sensitivity based on RQUICKY.

Insulin and adipokines allow for the communication of pancreas and adipose tissue with other body organs such as liver, to regulate, among others, energy metabolism and immune functions through not only alteration in blood concentrations, but also differential tissue regulation of receptor expression during the lactation cycle. Effects of leptin are mainly mediated by $L E P R b$ [8] and of adiponectin via $A D I P O R 1$ and $A D I P O R 2$, with $A D I-$ POR1 predominantly expressed in skeletal muscle and ADIPOR2 in liver [7]. Consistent with the literature [8, 38 ], in the present study, hepatic ADIPOR1 mRNA abundance was stable whereas $A D I P O R 2$ and $L E P R b$ mRNA increased in early lactation, counteracting reduced adiponectin and leptin concentrations around calving. This increase in ADIPOR2 and $L E P R b$ mRNA would favor a role of these hormones on insulin sensitivity in the liver, inducing fatty acid oxidation and preventing lipid accumulation [7, 38]. Hepatic INSR mRNA increased during pospartum and was greater at +55 days in all cows. Our data are consistent with reports that found greater liver INSR mRNA in control cows than cows with fatty liver disease or ketotic dairy cows [39],which suggested that reduced expression of INSR mRNA in the liver during early postpartum indicates that responses to insulin are markedly decreased, which might be due to insulin resistance.

\section{Effect of treatment on metabolic and endocrine profile and hepatic gene expression}

In the present study, although there were differences in milk NE and MP output as well as NE maintenance requirements between cow groups, the greater estimated DMI [14], thus, the greater estimated NEL and MP intakes, would explain differences in NE and MP balances between G0 and grazing cows (G1 and G2). The NE and MP balances indicated that grazing cows (G1 and G2 cows) mobilized greater amounts of tissue which was partially reflected in different BCS at +55 days between G2 and G0 cows.

Nevertheless, plasma NEFA concentrations in early lactation did not differ between G0 and G2 cows and were less than in G1 cows. The reduced NEFA and BHB concentrations in G0 cows would indicate a low rate of 
lipolysis and hepatic ketogenesis in agreement with their better energy balance [9]. In contrast, the reduced NEFA concentrations in G2 cows (when compared to G1 cows) that were accompanied with elevated BHB concentrations (not different than the observed in G1 cows), could probably be related to a differential tissue utilization of NEFA due to the increased walking and grazing activities in these cows. Plasma NEFA fuel, through mitochondrial fatty acid oxidation and Krebs cycle, energy production in muscle for muscle contraction or exercise, [3, 4]. Indeed, it has been suggested that increased walking activity could reduce plasma NEFA in dairy cows [40]. In addition, the greater plasma BHB in grazing cows (G1 and G2) could not only be related to an increased hepatic ketogenesis but also could reflect an increased synthesis of butyric acid in the rumen as fresh pastures were included in the diet [41]. The greater plasma insulin observed in G0 than G2 cows and IGF-I concentrations in G0 and G1 than G2 cows during the postpartum, was consistent with the greater non-fiber carbohydrate concentration, the reduced energy requirements for activity and the greater estimated energy balance in the former ones [10,42].

In the present study, the lowest concentrations of insulin and NEFA in G2 cows determined an increased RQUICKI in this group indicative of greater insulin sensitivity [35]. Adiponectin and leptin, which have insulin sensitizing actions, were the greatest in G2 cows during early lactation. Circulating adiponectin concentrations, insulin sensitivity, and basal fat oxidation rate have been showed to increase with exercise in humans [43]. Therefore, greater walking and grazing activity because of the increased number of sessions (two grazing sessions) and access time to pasture (9h) in G2 cows may explain these results.

We found and elevated expression of hepatic IGFBP6 mRNA in G2 cows consistent with Fenwick et al. [27] that highlight a role for this binding protein in undernutrition or energy deficiency. Moreover, Cummins et al. [44] reported that cows with lower fertility had greater abundance of IGFBP6 mRNA in the liver during the transition period in comparison with higher fertility cows. In agreement with the latter result, days to first ovulation were the longest and probability of cycling cows was the lowest in G2 cows. Indeed, Meikle et al. [9] reported that although there were no differences in milk production, dairy cows grazing medium sward herbage allowance showed a delayed reinitiation of ovarian cyclicity and lower BCS postpartum when compared to TMR and high herbage allowance grazing cows.

\section{Conclusion}

In this work, NE, but not MP, demands for maintenance and/or milk increased in G2 cows when compared with G1 and G0 cows, respectively. However, both NE and MP balances were less in grazing cows (G1 and G2) than in G0 cows. Metabolic-endocrine profiles of cows with different feeding strategies in early lactation reflected not only changes in milk energy output and energy balance but also in walking and grazing activity. Concentrations of insulin and IGF-I were increased in G0 cows whereas plasma adiponectin and both, insulin and leptin sensitivity were improved $\mathrm{G} 2$ cows. The greater energy demands and/or reduced energy balance in G2 cows when compared to both G1 and G0 cows implied a metabolic stress that impacted negatively on reproductive function (delayed reinitiation of ovarian cyclicity and reduced probability of cycling cows).

\section{Additional file}

Additional file 1. Primers used for the quantification of target and endogenous control gene cDNA.

\section{Authors' contributions}

AA participated in the design of the study and field work, performed all laboratory analyses, carried out the statistical analysis and drafted the manuscript. MC participated in the study design, supervised and advised AA in all the stages of the work (field work, laboratory and statistical analyses), and helped to draft the manuscript and corrected it. PC conceived the study, participated in its design and revised the manuscript. AM participated in the study design, supervised and advised in metabolite and hormone analyses, and help to draft the discussion of the manuscript and corrected the drafted manuscript. DM, MF and JG participated in the coordination of the field work and in the acquisition of data and samples. All authors read and approved the final manuscript.

\section{Author details}

1 Department of Animal Production and Pastures, School of Agronomy, Universidad de la República (UdelaR), Av. E. Garzón 780, C.P. 12900 Montevideo, Uruguay. ${ }^{2}$ Laboratory of Nuclear Techniques, School of Veterinary Medicine, Universidad de la República (UdelaR), C/Lasplaces 1550, C.P. 11600 Montevideo, Uruguay. ${ }^{3}$ Department of Health in Livestock Systems, School of Veterinary Medicine, Universidad de la República (UdelaR), EEMAC, Paysandú C.P. 6000, Uruguay.

\section{Acknowledgements}

The authors thank undergraduate student for assistance with animal management and sampling, and the staff of the Experimental Station Dr. Mario A, Cassinoni for animal care and assistance throughout the field work. The research that gives rise to the results presented in this publication was funded by the Agencia Nacional de Investigacion e Innovación under the code ANII \#POS_2011_1_3577 for the graduate scholarship awarded to A. Astessiano.

\section{Competing interests}

The authors declare that they have no competing interests.

Received: 24 June 2015 Accepted: 5 October 2015

Published online: 16 October 2015

\section{References}

1. Dillon P. Achieving high dry-matter intake from pasture with grazing dairy cow. In: Elgersma A, Dijkstra J, Tamminga S, editors. Fresh herbage for dairy cattle. Heidelberg: Springer-Verlag; 2006. p. 1-26.

2. Kolver ES, Muller LD. Performance and nutrient intake of high producing Holstein cows consuming pasture or a total mixed ration. J Dairy Sci. 1998;81:1403-11. 
3. Bauman DE. Regulation of nutrient partitioning during lactation: homeostasis and homeorhesis revisited. In: Cronje PJ, editor. Ruman physiology: digestion, metabolism and growth and growth and reproduction. New York: CAB Publishing; 2000. p. 311-27.

4. Drackley JK, Beaulieu AD, Elliott JP. Responses of milk fat composition to dietary fat or nonstructural carbohydrates in Holstein and Jersey cows. J Dairy Sci. 2001;84:1231-7.

5. Lucy MC. Functional differences in the growth hormone and insulin-like growth factor axis in cattle and pigs: implications for post-partum nutrition and reproduction. Reprod Domest Anim. 2008;43:31-9.

6. Block SS, Butler WR, Ehrhardt RA, Bell AW, Van Amburgh ME, Boisclair YR. Decreased concentration of plasma leptin in periparturient dairy cows is caused by negative energy balance. J Endocrinol. 2001;171:339-48.

7. Kadowaki T, Toshimasa Y, Kubota N, Hara K, Ueki K, Tobe K. Adiponectin and adiponectin receptors in insulin resistance, diabetes, and the metabolic syndrome. J Clin Invest. 2006;116:1784-92.

8. Thorn SR, Ehrhardt RA, Butler WR, Quirk SM, Boisclair YR. Insulin regulates hepatic leptin receptor expression in early lactating dairy cows. Am J Physiol Regul Integr Comp Physiol. 2008;295:1455-62.

9. Meikle A, Adrien ML, Mattiauda DA, Chilibroste P. Effect of sward condition on metabolic endocrinology duringthe early postpartum period in primiparous grazing dairy cows and its association with productive and reproductive performance. Ani. Feed Sci Technol. 2013;186:139-47.

10. Wales WJ, Marett LC, Greenwood JS, Wright MM, Thornhill JB, Jacobs JL, et al. Use of partial mixed rations in pasture-based dairying in temperate regions of Australia. Anim Prod Sci. 2013;53:1167-78.

11. Chilibroste $\mathrm{P}$, Soca $\mathrm{P}$, Mattiauda DA, Bentancur $\mathrm{O}$, Robinson $\mathrm{PH}$. Short term fasting as a tool to design effective grazing strategies for lactating dairy cattle: a review. Aust J Agr Res. 2007:47:1075-84.

12. Chilibroste P, Mattiauda DA, Bentancur O, Soca P, Meikle A. Effect of herbage allowance on grazing behavior and productive performance of early lactation primiparous holstein cows. Anim Feed Sci Technol. 2012;173:201-9.

13. Edmonson AJ, Lean IJ, Weaver LD, Farver T, Webster G. A body condition scoring chart for Holstein dairy cows. J Dairy Sci. 1989;72:68-78.

14. NRC. Nutrient requirements of dairy cattle. 7 rev ed. Washington: National Academies Press; 2001

15. Fajardo M, Mattiauda DA, Motta G, Genro TC, Meikle AG, Carriquiry M. Use of mixed rations with different access time to pastureland on productive responses of early lactation Holstein cows Livest Sci. 2015 (in press).

16. Carriquiry M, Webe WJ, Fahrenkrug SC, Crooker BA. Hepatic gene expression in multiparous Holstein cows treated with bovine somatotropin and fed n-3 fatty acids in early lactation. J Dairy Sci. 2009;92:4889-900.

17. Adrien ML, Mattiauda DA, Artegoitia V, Carriquiry M, Motta G, Bentancur $\mathrm{O}$, Meikle A. Nutritional regulation of body condition score at the initiation of the transition period in primiparous and multiparous dairy cows under grazing conditions: milk production, resumption of post-partum ovarian cyclicity and metabolic parameters. Animal. 2012;6:292-9.

18. Astessiano AL, Perez-Clariget R, Quintans G, Soca P, Meikle A, Crooker BA, et al. Metabolic and endocrine profiles and hepatic gene expression in periparturient, grazing primiparous beef cows with different body reserves. Livest Sci. 2014;170:63-71.

19. Raddatz JR, Elias AN, Whisnant CS. Measurements of Adiponectin in lactating dairy cows. J Anim Sci. 2008;86(E-Suppl.2):60.

20. Astessiano AL, Perez Clariget R, Quintans G, Soca P, Carriqury M. Effects of a short-term increase in the nutritional plane before the mating period on metabolic and endocrine parameters, hepatic gene expression and reproduction in primiparous beef cows on grazing conditions. J Anim Physiol Anim Nutr. 2012;96:535-44

21. Pfaffl MW. Quantification strategies in real-time PCR. In: Bustin SA, editor. A-Zof Quantitative PCR. La Jolla: International University Line (IUL); 2004. p. 89-113.

22. Perseghin G, Caumo A, Caloni M, Testolin G, Luzi L. Incorporation of the fasting plasma FFA concentration into quicki improves its association with insulin sensitivity in nonobese individuals. J Clin Endocrinol Metab. 2001;86:4776-81.

23. Säkkinen $\mathrm{H}$. Title of subordinate document. In: Variation in the blood chemical constituents of reindeer: significance of season, nutrition and other extrinsic and intrinsic factors. Oulu: Universityof Oulu; 2005. http:// urn.fi/urn:isbn:9514277732
24. Kobayashi Y, Boyd CK, Bracken CJ, Lamberson WR, Keisler DH, Lucy MC Reduced growth hormone receptor (GHR) messenger ribonucleic acid in liver of periparturient cattle is caused by a specific down-regulation of GHR 1 A that is associated with decreased insulin-like growth factor I. Endocrinology. 1999;140:3947-54.

25. Butler ST, Marr AL, Pelton SH, Radcliff RP, Lucy MC, Butler WR. Insulin restores $\mathrm{GH}$ responsiveness during lactation-induced negative energy balance in dairy cattle: effects on expression of IGF-I and GH receptor 1A J Endocrinol. 2003;176:205-17.

26. Jones J, Clemmons DR. Insulin-like growth factors and their binding proteins: biological actions. Endocr Rev. 1995;16:3-34.

27. Fenwick MA, Fitzpatrick R, Kenny DA, Diskin MG, Patton J, Murphyd JJ, et al. Interrelationships between negative energy balance (NEB) and IGF regulation in liver of lactating dairy cows. Domes Anim Endocrinol. 2008;34:31-44.

28. Kessler EC, Gross JJ, Bruckmaier RM. Different adaptation of IGF-I and its IGFBPs in dairy cows during a negative energy balance in early lactation and a negative energy balance induced by feed restriction in mid-lactation. Vet Med. 2013;58:459-67.

29. Beattie J, Allan GJ, Lochrie JD, Flint DJ. Insulin-like growth factor-binding protein-5 (IGFBP-5): a critical member of the IGF axis. Biochem J. 2006:395:1-19.

30. Piechotta M, Kedves K, Gil Araujo M, Hoeflich A, Metzger F, Heppelmann $M$, et al. Hepatic mRNA expression of acid labile subunit and deiodinase 1 differs between cows selected for high versus low concentrations of insulin-like growth factor 1 in late pregnancy. J Dairy Sci. 2013;96:3737-49.

31. Pfaffl MW, Georgieva TM, Georgiev IP, Ontsouka E, Hageleit M, Blum JW. Real-time RT-PCR quantification of insulin-like growth factor (IGF)-1, IGF-1 receptor, IGF-2, IGF-2 receptor, insulin receptor, growth hormone receptor, IGF-binding proteins 1, 2 and 3 in the bovine species. Domest Anim Endocrinol. 2002;22:91-102.

32. Walsh SW, Matthews JA, Browne N, Forde MA, Crowe M, Mihm M, et al. Acute dietary restriction in heifers alters expression of genes regulating exposure and response to gonadotrophins and IGF in dominant follicles. Anim Reprod Sci. 2012;133:43-51.

33. Gadd TS, Osgerby JC, Wathes DC. Regulation of insulin-like growth factor binding protein- 6 expression in the reproductive tract throughout the estrous cycle and during the development of the placenta in the ewe. Biol Reprod Suppl. 2002;67:1756-62.

34. Wang TH, Chang CL, Wu HM, Chiu YM, Chen CK, Wang HS. Insulin-like growth factor-II (IGF-II), IGF-binding protein-3 (IGFBP-3), and IGFBP-4 in follicular fluid are associated with oocyte maturation and embryo development. Fertil Steril. 2006;86:1392-401.

35. Holtenius P, Holtenius K. A model to estimate insulin sensitivity in dairy cows. Acta Vet Scand. 2007;49:29.

36. Singh SP, Häussler S, Heinz JF, Akter SH, Saremi B, Müller U, et al. Lactation driven dynamics of adiponectin supply from different fat depots to circulation in cows. Domest Anim Endocrinol. 2014;47:35-46.

37. Weber C, Hametner C, Tuchscherer A, Losand B, Kanitz E, Otten W, et al. Variation in fat mobilization during early lactation differently affects feed intake, body condition, and lipid and glucose metabolism in high-yielding dairy cows. J Dairy Sci. 2013;96:165-80.

38. Saremi B, Sauerwein H, Dänicke S, Mielenz M. Technical note: identification of reference genes for gene expression studies in different bovine tissues focusing on different fat depots. J Dairy Sci. 2012;95:3131-8.

39. Liu GE, Hou Y, Zhu B, Cardone MF, Jiang L, Cellamare A, et al. Analysis of copy number variations among diverse cattle breeds. Genome Res. 2010;20:693-703.

40. Adewuyi AA, Gruys E, Van Eerdenburg J. Non esterified fatty acids (NEFA) in dairy cattle. A review. Vet Q. 2005;27:117-26.

41. Vibart RE, Burns JC, Fellner V. Effect of replacing total mixed ration with pasture on ruminal fermentation. Prof Anim Sci. 2010;26:435-42.

42. Buyse M, Ovesjö ML, Goïot H, Guilmeau S, Péranzi G, Moizo L, et al. Expression and regulation of leptin receptor proteins in afferent and efferent neurons of the vagus nerve. Eur J Neurosci. 2001;14:64-72.

43. Simpson KA, Singh MAF. Effects of exercise on adiponectin: a systematic review. Obesity. 2008;16:241-56.

44. Cummins SB, Waters SM, Evans ACO, Lonergan P, Butler ST. Genetic merit for fertility traits in Holstein cows: III. Hepatic expression of somatotropic axis genes during pregnancy and lactation. J Dairy Sci. 2012;95:3711-21. 